13. Уголовно-процессуальный кодекс Республики Грузия : Закон Республики Грузия от 09.10.2009 г. URL: http://pravo.org.ua/files/Criminal\%20justice/_-09_10_2009.pdf.

14. Уголовно-процессуальный кодекс Республики Молдова : Закон Республики Молдова от 14.03.2003 г. URL: http://pravo.org.iia/files/Criminal\%20justice/_-09_10_2009.pdf.

15. Верхогляд-Герасименко О.В. Забезпечення майнових прав особи при застосуванні заходів кримінально-процесуального примусу : монографія. Харків : Юрайт, 2012. 216 с.

16. Відеозапис із камери магазину, яка працювала в момент обшуку, суд не прийняв як доказ. URL: https://ua.korrespondent.net/city/kiev/4051102-yuvelirnyi-mahazyn-vidsudyv-25-mlnhryven-za-pohrabuvannia-pid-chas-obshuku.

УДК 343.85:343.347

DOI https://doi.org/10.32844/2618-1258.2019.3-2.36

ТОММА Р.П., ШЕВЧУК О.О.

\title{
ОРГАНІЗАЦЙНІ ОСНОВИ ПРОТИДІЇ ЗЛОЧИНАМ У СФЕРІ ОБІГУ ФАЛЬСИФІКОВАНИХ ЛІКАРСЬКИХ ЗАСОБІВ
}

Стаття присвячена вивченню шляхів удосконалення організаційних основ протидії злочинам у сфері обігу фальсифікованих лікарських засобів, суспільної небезпеки цих злочинів та розробці заходів щодо їх усунення. Також у статті на основі практичних та наукових напрацювань визначено типові способи вчинення злочинів у сфері обігу фальсифікованих лікарських засобів. Визначено такі типові способи вчинення правопорушень у процесі організації та проведення процедур державної закупівлі лікарських засобів та виробів медичного призначення: закупівля лікарських засобів, виробів медичного призначення фармацевтичних послуг повністю або частково за рахунок державних коштів без проведення процедури конкурсних торгів на суму, що дорівнює або перевищує 100 тис. грн; закупівля робіт повністю або часткоаво за рахунок державних коштів без проведення процедури конкурсних торгів на суму, що дорівнює або перевищує 300 тис. грн; незаконний поділ замовником лікарських засобів та медичного обладнання на частини 3 метою уникнення проведення процедури відкритих торгів, що призводить до перевитрат державних коштів; встановлення замовником торгів дискримінаційних умов до деяких учасників процедури закупівлі. 3'ясовано, що правовий важіль впливу - це основний координаційний інструмент регулювання з метою зменшення злочинних проявів у сфері державних закупівель. 1 червня 2010 р. прийнято Закон України «Про здійснення державних закупівель», що встановлює правові та економічні засади здійснення закупівель товарів, робіт і послуг за державні кошти. Зроблено висновок, що сфера обігу лікарських засобів та медичного обладнання $\epsilon$ функціонально орієнтованим елементом національної безпеки, вбудованим в механізм бюджетного сектора економіки, ресурсно-економічного та фінансового забезпечення галузей державного управління. Протидія злочинам у сфері обігу фальсифікованих лікарських засобів полягає у виявленні причин та умов їх вчинення та розробці заходів щодо їх усунення, забезпеченні протидії кримінально-корупційним проявам витрачання бюджетних коштів під час закупівлі лікарських засобів, дотриманні необхідної їх якості та максимально повного використання принципу прозорості учасниками ринку лікарської продукції.

Ключові слова: фальсифіковані лікарські засоби, держсавні закупівлі, протидія злочинам, лікарські засоби, вироби медичного призначення, розпорядники державних коштів.

(C) ТОММА Р.П. - кандидат юридичних наук, доцент, доцент кафедри оперативно-розшукової діяльності (Національна академія внутрішніх справ)

(C) ШЕВЧУК О.О. - кандидат юридичних наук, доцент, доцент кафедри забезпечення фінансової безпеки та фінансового розслідування (Навчально-науковий інститут № 1 Національної академії внутрішніх справ) 
The article is devoted to the study of ways to improve the organizational framework for counteracting crimes in the area of counterfeit drugs circulation, the social danger of these crimes and the development of measures to overcome them. Also in the article, based on practical and scientific developments, typical ways of committing crimes in the sphere of counterfeit medicines are determined. Defined typical uses of human rights budgets in organizing and conducting the procedures used to purchase medical enterprises and medical directory products: People who purchase hospitals are produced by health professionals using a private service, without any international competition requiring 100 thousand UAH; You can buy your own or private in order to preserve your identity without touching competitive requiring 300 thousand UAH; reliable distribution of custom medicines and medical equipment used for use in use is used to open bidding; install custom discs that have been made for everyone involved. Given that legal action is in place, it is a major coordination tool for regulating the use of reducing criminal investigations in other public procurement. On June 1,2010, it is necessary to adopt the Law of Ukraine "Continuing State Appetizers", which have the right and economic basis for purchasing goods that work and use public funds. It is made appropriate that the sphere of defense medicines and medical equipment is a functionally preserved element of national security, which is used within the budget sector of economy, resourceeconomic and appropriate economic management. The counteraction of criminals in their local central office of falsified hospitals uses trusted persons and employees who trust and try to achieve when they try to counteract the criminal-corrupt individuals who reveal a holistic and effective issue and still demand when they purchase meds when purchasing times when they exist, and often always Remember the principles of transparency between drug market players.

Key words: counterfeit medicines, government Procurement, counteracting crimes, Medicines, medical products, public funds managers.

Вступ. Економічні, соціальні та політичні процеси, які відбуваються в країні, впливають на характер злочинності, адже змінюється ії структура, механізми та способи вчинення злочинів. Ускладнює ситуацію загальне зростання рівня злочинності, поширення тіньової економіки й корупції, а також недосконалість законодавчої бази. Вплив ринкових відносин кардинально змінив характер економічної діяльності суб'єктів господарювання, що призвело до виникнення нових злочинів, які пов’язані з фальсифікацією лікарських засобів (далі - ЛЗ). Виробництво і розповсюдження фальсифікованих лікарських засобів створює загрозу для життя та здоров'я населення України, при цьому наносяться значні збитки легальним виробникам фармацевтичної продукції та державному бюджету. Згідно з оцінками Всесвітньої організації охорони здоров'я (ВОО3) у розвинених країнах кількість фальсифікату становить близько $10 \%$, а в країнах третього світу - половину всіх лікарських засобів. В Україні, за різними версіями, продається до 50\% підроблених ліків. Фальсифіковані ліки несуть високу загрозу життю та здоров’ю громадян України, особливо якщо врахувати, що згідно з даними ВООЗ найбільша кількість підробок - 42\% - антибіотики, $18 \%$ - психотропні речовини [7]. Злочини, пов'язані з обігом фальсифікованих лікарських засобів, вчиняються в умовах таємності, неочевидності. Особи, які їх учиняють, приховують зміст злочинної діяльності та сліди злочинів, оскільки зацікавлені в постійному продовженні злочинної діяльності та отриманні неконтрольованого доходу від реалізації фальсифікованих лікарських засобів [4, с. 2]. Ці та інші фактори зумовлюють потребу перегляду традиційних підходів до розкриття злочинів, що пов'язані з фальсифікацією лікарських засобів, доповнення науково-методичної бази новими методиками. Кримінальний кодекс України у 2011 році був доповнений ст. $321^{1}$ «Фальсифікація лікарських засобів або обіг фальсифікованих лікарських засобів», у 2012 році - ст. $321^{2}$ «Порушення встановленого порядку доклінічного вивчення, клінічних випробувань і державної реєстрації лікарських засобів». Однак статистичні дані не свідчать про активну діяльність оперативних підрозділів щодо виявлення та розкриття зазначених злочинів [2]. У 2013 р. було виявлено 66 злочинів, пов'язаних 3 виготовленням та реалізацією фальсифікованих лікарських засобів, а направлено до суду лише 27 справ (що становить 40,9\%); у 2014 р. - 40 та 7; у 2015 р. - 40 та 10 (25\%); у 2016 р. - 52 та 11 $(21,2 \%) ;$ у 2017 р. - 44 та 10 (22,7\%) [12], що свідчить про негативну тенденцію їх виявлення та документування. Водночас відносна новизна зазначених видів злочинів зумовила недостатньою ефективністю діяльності правоохоронних органів щодо їх виявлення та попередження. Значною 
мірою підвищити ефективність діяльності правоохоронних органів допоможе створення і налагодження чіткого і науково обгрунтованого механізму виявлення причин та умов вчинення злочинів на фармацевтичному ринку та їх нейтралізації. Для цього спочатку необхідно провести наукове дослідження з детальним розробленням заходів оперативно-розшукової профілактики злочинів цього напряму з метою їх виявлення на стадії підготовки.

Певні аспекти проведення оперативно-розшукових заходів щодо протидії обігу фальсифікованої лікарської продукції, тактики виявлення та документування окремих злочинів у цій сфері, взаємодії з іншими правоохоронними органами та органами, що контролюють обіг фармацевтичної продукції, досліджено в роботах В.І. Василинчука, А.М. Лисенка, С.I. Ніколаюка, Д.Й. Никифорчука, Р.О. Ніколаєнко та інших, проте дане питання потребує комплексного аналізу фармацевтичного ринку, який повинен об'єднати роботу оперативних підрозділів та системний економіко-правовий аналіз (який здійснюється суб'єктами державного контролю фармацевтичного ринку), що дозволить не тільки отримати реальну картину стану оперативної обстановки на фармацевтичному ринку, але й виявити конкретні причини та умови вчинення цих злочинів, персоніфікувати осіб, які є організаторами зазначених злочинів (наприклад, корумпованих посадовців контролюючих органів).

Постановка завдання. 3 огляду на наведене метою статті є дослідження шляхів удосконалення організаційних основ вчинення злочинів у сфері обігу фальсифікованих лікарських засобів, вивчення суспільної небезпеки цих злочинів та розробка заходів щодо їх подолання.

Результати дослідження. На жаль, досі залишається нагальною проблема фіктивних торгів за державні кошти та торгів ліками за завищеними цінами, монополістичної змови учасників, просування на ринок тільки «своїх» фармацевтичних (фіктивних) фірм, так зване кумівство. На жаль, у цій сфері досить поширеними і звичними сьогодні стали такі супутні негативні явища, як корупція, відкати, узгоджені дії, безпосередня участь посадових осіб, державних службовців та депутатів усіх рівнів і членів їх сімей у комерційній діяльності для одержання особистого чи корпоративного прибутку, надання пільг для своєї корпоративної групи з відтягненням державних ресурсів, використання посадовими особами, державними службовцями, депутатами, політичними діячами підставних осіб та родичів у комерційних структурах з метою здобуття особистого чи корпоративного прибутку, використання службового становища для маніпулювання інформацією з метою одержання особистої та корпоративної вигоди [4, с. 1].

Типові способи вчинення правопорушень у процесі організаиії та проведення процедур державної закупівлі лікарських засобів та виробів медичного призначення (далі - ВМП):

- здійснення закупівлі лікарських засобів, виробів медичного призначення, фармацевтичних послуг повністю або частково за рахунок державних коштів без проведення процедури конкурсних торгів на суму, що дорівнює або перевищує 100 тис. грн;

- здійснення закупівлі робіт (обслуговування медичного обладнання) повністю або частково за рахунок державних коштів без проведення процедури конкурсних торгів на суму, що дорівнює або перевищує 300 тис. грн;

- незаконний поділ замовником лікарських засобів та медичного обладнання на частини 3 метою уникнення проведення процедури відкритих торгів, що призводить до перевитрат державних коштів;

- встановлення замовником торгів дискримінаційних умов для деяких учасників процедури закупівлі (наявність у документації конкурсних торгів вимог, що обмежують конкуренцію та призводять до дискримінації учасників (зокрема, необгрунтоване допущення певного учасника 3 пропозицією до участі у торгах за умови, що вона не повною мірою відповідає вимогам документації конкурсних торгів (кваліфікаційної документації); встановлення дискримінаційних вимог щодо кваліфікації учасників торгів, технічної специфікації лікарських засобів, механізму оцінки пропозицій конкурсних торгів)).

Існують певні умови, пов'язані з доступністю лікарського забезпечення для населення.

Причини виникнення цих умов:

- нераціональне розміщення аптечних закладів;

- зменшення кількості державних аптек;

- зменшення кількості виробничих відділів аптек (екстемпоральне виготовлення ліків);

- посилення тенденцій поглинання, об’єднання виробників фармацевтичної продукції та посередників;

- монополізація ринку великими аптечними мережами;

- перехід виробників фармацевтичної продукції на стандарти GMP. 
Прямі наслідки дії таких умов:

- неможливість забезпечення пільгових категорій хворих необхідними Л3; цевості;

- зниження показників доступності лікарського забезпечення, особливо в сільській міс-

- зменшення можливості впливу на ціни ЛЗ (раціонального ціноутворення);

- неможливість придбання ліків малозабезпеченими категоріями населення за низькими цінами;

- зменшення асортименту дешевих ЛЗ для малозабезпечених категорій хворих;

- неможливість індивідуального підходу до лікування захворювань;

- втрата аптеками фармацевтичних функцій;

- підвищення цін на ЛЗ у зв'язку з модернізацією виробництва за стандартами GMP.

Крім того, існують умови, пов'язані з особистими якостями посадових осіб, які супроводжують прочес бюджетних закупівель.

Причини виникнення таких умов:

- неправомірні дії посадових осіб, які займаються державними замовленнями;

- недостатня кваліфікація посадових осіб, які формують асортимент ЛЗ для закупівлі та складають тендерну документацію (справи).

Прямі наслідки дії таких умов:

- недовіра потенційних постачальників або недержавних організацій (фондів) та приватних осіб до державних організацій, що проводять тендерні торги;

- завищення закупівельних цін на ЛЗ;

- нераціональне використання бюджетних коштів, можливі перевитрати державних коштів;

- нераціональна фармакотерапія;

- помилкове планування необхідних обсягів ЛЗ, форм випуску або доз ЛЗ, особливо для лікування пацієнтів з новими захворюваннями;

- відсутність необхідних ЛЗ або їх надлишок;

- невірне оформлення документації, помилки в доведенні ефективності, кількості, назві тощо.

Опосередковані наслідки дії таких умов:

- постачання непотрібних ЛЗ (у невідповідних обсягах, формі або дозуванні);

- тендер не відбувається або вважається таким, що не відбувся;

- вимушене придбання ЛЗ хворими за особисті кошти;

- підвищення витрат на лікування;

- зниження економічного ефекту від централізованих закупівель;

- зниження рівня медичної та лікарської допомоги населенню;

- обмежене фінансування цільових програм із недержавних джерел;

- зниження показників доступності лікарського забезпечення та ефективності лікування [11].

Пропонуємо такі заходи щодо усунення причин та умов вчинення злочинів у сфері обігу фальсифікованих лікарських засобів:

1) правовий важіль впливу - це основний координаційний інструмент регулювання з метою зменшення злочинних проявів у сфері державних закупівель. 1 червня 2010 р. прийнятий Закон України «Про здійснення державних закупівель», що встановлює правові та економічні засади здійснення закупівель товарів, робіт і послуг за державні кошти. Його метою є створення конкурентного середовища у сфері державних закупівель лікарських засобів, запобігання проявам корупції у цій сфері, розвиток добросовісної конкуренції, забезпечення раціонального та ефективного використання державних коштів;

2) методи кадрового впливу. 3 огляду на неможливість усунути прояви злочинності шляхом лише ретроспективної відповідальності вважаємо за доцільне вивчити та запровадити заходи позитивної відповідальності, тобто встановлення певних нагород, заохочень тощо для учасників процесу виготовлення та закупівель лікарських засобів з боку замовника. Головний мотив скоєння правопорушень у сфері фальсифікації лікарських засобів - це матеріальна користь працівників фірм-замовників - службових (посадових) осіб. 3 огляду на необхідність стимулювати зацікавленість в інтересах замовників (а не окремого учасника) варто розробити методику заохочень службових (посадових) осіб замовника;

3) з метою недопущення масового вливання на ринок фальсифікованої лікарської продукції необхідно вжити організаційних або координаційних заходів у співпраці між контролюючими органами у сфері обігу лікарських засобів та виробів медичного призначення. Слід розробити спільний міжвідомчий координаційний підрозділ (наприклад, наглядову раду з питань регулювання виготовлення та реалізації медичних засобів при МОЗ України, контрольно-розвідувальне 
управління у сфері обігу лікарських та медичних виробів Департаменту захисту економіки при Національній поліції України, СБУ тощо), розробити єдину систему виявлення та документування злочинів у сфері державних закупівель та фальсифікації лікарських засобів, методичні рекомендації щодо порядку проведення перевірок фармацевтичних компаній та інших учасників обігу лікарської продукції на предмет виготовлення фальсифікованих лікарських засобів;

4) психологічний метод впливу - це превентивний захід запобігання виникненню злочинних проявів. Інструментарій психології слід застосовувати як серед працівників фармацевтичного ринку, розпорядників бюджетних, державних коштів, так і серед працівників контролюючих органів та органів, уповноважених здійснювати вплив, координацію та контроль у сфері виготовлення та реалізації ЛЗ та ВМП [11].

Висновки. Отже сфера обігу ЛЗ та медичного обладнання є функціонально орієнтованим елементом національної безпеки, вбудованим в механізм бюджетного сектору економіки, ресурсно-економічного та фінансового забезпечення галузей державного управління. Аналіз розвитку стану злочинності у сфері обігу ЛЗ в Україні у 2014-2017 роках [12], умов та причин вчинення таких злочинів засвідчив появу нових способів вчинення таких правопорушень, що призвело до значного послаблення конкурентного середовища, зменшення питомої ваги відкритих і прозорих державних закупівель ЛЗ та ВМП, суттєвого зростання злочинності у сфері незаконного та неефективного використання коштів Державного бюджету України. Протидія злочинам у сфері обігу фальсифікованих лікарських засобів полягає у виявленні причин та умов їх вчинення та розробці заходів щодо їх усунення, забезпеченні протидії кримінально-корупційним проявам витрачання бюджетних коштів під час закупівлі лікарських засобів, дотриманні необхідної їх якості та максимально повного використання принципу прозорості учасниками ринку лікарської продукції.

Список використаних джерел:

1. Конституція України : Закон України від 28 червня 1996 р. № 254к/96-ВР / Верховна Рада України. Відомості Верховної Ради Украӥни. 1996. № 30. Ст. 141.

2. Кримінальний кодекс України : Закон України від 5 квіт. 2001 р. / Верховна Рада України. Відомості Верховної Ради України. 2001. №№ 25, 26. Ст. 131.

3. Кодекс України про адміністративні правопорушення (станом на 20.04.2011р.). Відомості Верховної Ради УРСР. 1984. № 51. Ст. 1122.

4. Ніколаєнко Р.А. Актуальні проблеми протидії злочинам, пов’язаним з виготовленням та розповсюдженням фальсифікованих лікарських засобів. Актуальні проблеми досудового розслідування : тези доп. Міжнар. наук.-практ. конф., м. Київ, 5 лип. 2017 р. Київ : Нац. акад. внутр. справ, 2017. С. 172-174.

5. Остап'юк М.В. Господарсько-правове регулювання державних закупівель лікарських засобів та медичних виробів : дис. ... канд. юрию. наук : 12.00 .04 «Господарське право; господарсько-процесуальне право» ; Національний університет «Одеська юридична академія». Одеса, 2015. C. 253

6. Про здійснення державних закупівель : Закон України від 10 квіт. 2014 р. № 1197-VII / Верховна Рада України. Відомості Верховної Ради Украӥни. 2014. № 24. Ст. 883.

7. Представництво Всесвітньої організації охорони здоров'я (ВООЗ) в Україні / офіційний сайт. URL: http://geneva.mfa.gov.ua/ua/ukraine-io/who.

8. Рахункова палата України / Офіційний вебсайт Рахункової палати України. URL: http://www.ac-rada.gov.ua/

9. Рішення Конституційного Суду України у справі за конституційним поданням 53 народних депутатів України щодо офіційного тлумачення положення частини третьої статті 49 Конституції України «у державних і комунальних закладах охорони здоров'я медична допомога надається безоплатно» (справа про безоплатну медичну допомогу) м. Київ, 29 травня 2002 року. Справа № 1-13/2002 N 10-рп/2002.

10. Раковська Ю.В. Фальсифікат лікарських засобів як найприбутковіший вид транснаціональної злочинної діяльності. Митна справа. 2014. № 1 (2.1). C. 148-154. URL: http://nbuv.gov. ua/UJRN/Ms_2014_1(2).

11. Євтушенко О.М., Мнушко 3.М., Немцова В.Д. Вивчення ризиків у сфері державних закупівель лікарських засобів та виробів медичного призначення. Науковий вісник «Управління, економіка та забезпечення якості в фармачії». 2010. № 4 (12). С. 50-54.

12. Єдиний звіт про кримінальні правопорушення : затверджений Наказом ГПУ № 100 від 23 жовт. 2012 p. URL: https://www.gp.gov.ua/ua/stst. 